\title{
Adolescents and Internet Cafes
}

\section{Yasin DEMiR}

Firat University, Faculty of Education, Department of Educational Sciences Mustafa KUTLU

Inonu University, Faculty of Education, Department of Educational Sciences

\section{Abstract:}

The purpose of this study was to examine the levels of aggression of adolescents playing game in the internet cafes located in the city of Elazig in terms of different variables (gender, academic achievement, and most played game type). The universe of study consists of high school students playing game in the internet cafes in the city of Elazığ in Turkey. The sample of study consists of 119 females, and 268 males, totally 387, high school students playing game in the internet cafes. As the research data collection tool, Aggression Scale developed by Tuzgol were used. According to the findings obtained from the study, the levels of agression in male students are higher than female students, the levels of agression in students having low levels of academic achievement are higher than the levels of agression in students having high levels of academic achievement, the levels of agression in the students who play war and violent games are higher than the levels of agression in the students who play different types of games.

Keywords: Internet cafe, Aggression, Game type.

Inönü University

Journal of the Faculty of Education

Vol 19, No 3, 2018

pp. $452-460$

DOI: $10.17679 /$ inuefd.420378

\section{Suggested Citation}

Demir, Y. \& Kutlu, M. (2018). Adolescents and Internet Cafes, Inonu University Journal of the Faculty of Education, 19(3), 452-460. DOI: 10.17679/inuefd.420378 


\section{INTRODUCTION}

According to 2017 census based on domicile records, adolescent population in Turkey is approximately 13 millions, in other words, approximately $6 \%$ of the population are adolescents (TUIK, 2018). While World Health Organization (WHO) defined the adolescence as a period of 10-19 years of age, where severe changes in social interaction and communications as well as physical and psychological changes are observed in an individual (WHO, 2012), Kılıç suggested that maximum physical power was reflected in this period and both joy and sorrow are experienced intensely and adolescence was a transition period between childhood and adulthood (Kılıç, 2013). The period of adolescence, which is a transition period from childhood to adulthood, is also a difficult and complicated time for the adolescent. Adolescents mature physically in that period, but develop socially and psychologically as well. In this period, social and academic responsibilities of adolescents increase, while the beliefs and values of individuals form. In this period, the influence of parents on the adolescent diminishes while peer pressure is experienced more heavily. There are several behavioral changes in adolescents as a result of this significant period. These behavior affect the life of the individual at a great extend during adolescence and in subsequent periods of development (Gençtarım Kuru, 2010). Adolescents, who are the future of the society, are affected by developmental components such as genetic, social, familial, physical, psychological, environmental, economical and physiological factors (Griffiths, 1999; Marcus, 2007; Polcari et al., 2013; Rink, Tricker and Harvey, 2007). In addition to growing up, adolescents change in many other respects as well. Adolescents, who were manageable, silent and amenable until that time, start to act rebellious and headstrong all of a sudden. Running away from home and insubordination to authority follow this situation (Kılıç, 2013). Edmonson and Bullock (1998) reached findings that high school students displayed more aggressive behavior than primary school students in a study they conducted (Donat Bacl, 2011).

Following the opening of the first Internet Café in 1994 in England (Aktaş, 2006), they became widespread in the world towards the end of 1990's and today, Internet Cafes are used as a gathering place for adolescents, and they are frequently preferred by adolescents because of the facilities they provide to access information, do shopping, communicate, have fun as they socialize (Ögel, 2012). As the Internet Cafes became widespread, adolescents often preferred to spend time there because they could do their homework there by accessing information easily, they could chat with their friends online and they could play games (Binark and Bayraktutan-Sütcü, 2007). Other factors affecting the individuals to prefer Internet Cafes are speedy Internet connections in Internet Cafes, and reasonable hourly pricing (Çağlayan, 2001).

Internet Cafes are useful in making use of adolescents' pastime, facilitating their access to information and research. On the other hand, it has been argued that it affects the development of the individual in a negative manner when misused without control and used insensibly (Tarı Cömert and Kayıran, 2010). Using Internet Cafes for game play is one of the leading factors why adolescents frequently prefer Internet Cafes. Ministry of Interior took action and banned certain games from Internet Cafes because of the high prevalence of games with aggression played there (Binark and Bayraktutan-Sütçü, 2007).

There are several definitions of aggression that influences adolescent's life quality and relations with other individuals negatively. According to Freedman, Sears and Carlsmith, aggression is any behavior or action aimed in hurting others (Yavuzer, 2009). In its broadest sense, Butovskaya and Kozintsev (1999) defined aggression as a perpetual behavior with biological and social precepts and ending in harming a living or inanimate object (cited in Kurtoğlu, 2009). Not all behavior inflicting pain or destroying property are aggressive. Aggressor and the society must consider the act as aggression. For instance, traditional bull fights or bull stampedes in Spain are considered to be a part of the culture and a sport, while they result in pain and destruction of property and are not considered as aggression (Kumru Sarıca, 2008). Furthermore, aggression aims to damage or hurt something or somebody. To determine if a behavior is aggressive or not, the intent should be investigated. A behavior is considered as aggression when it is executed to inflict harm, but not when there is no such intent. For example, there is a significant difference between a doctor amputating the hand of a patient due to gangrene and a torturer cutting off one's hand. Even though they have the same result (a man losing a hand), the intent of the behavior is different (Kağıtçıbaşı, 2009). Environmental factors play an important role in the development of adolescents (Çavuş, Ayhan and Tuncer 2016). It is emphasized that computer games affect the behavior of adolescents (Fikkers, Piotrowski and Valkenburg, 2016). 
Theories explained the reasons of aggression in different manners. Freud considered aggression as an important derivative of death instinct and expressed it as a deflection of the individual's destructive dispositions towards himself towards the objects in the external world (Corey, 2008). Social Learning theory refused the notion that aggression was an instinct or an impulse caused by frustration, and suggested that aggression was no different than other learned reactions. According to Bandura, the behavior of aggression is acquired by learning (Yavuzer, 2009). Karen Horney suggested that love and hate, aggression and subversion were not instinctive and acquired as a result of the culture. She accepted that these emotions played a significant role in human relations. She mentioned familial and cultural factors by stating that the characteristics of the neurotic environment parents' attitudes create determine the choice of the child to provide self-security via compliance, aggression or introversion (Geçtan, 1994).

The intensity of the emotion of aggression and its conversion into behavior change depending on the individual. It is determined by the conditions the individual lives in. In a way, aggression is externalized proportionally with frustration. Aggression in adolescence is rather directed to destroy or hurt an individual or an object. Aggressive behavior in adolescence might lead to activities of violence and bullying such as joining a gang, theft with gang members and other friends, skipping classes or joining illegal entities, using knives or other devices (Yavuzer, 2009). Aggression has several types ranging from social and verbal aggression to physical aggression and even serious violence. Physical aggression includes violent crimes such as inflicting bodily damage, threats and thievery, heist, and murder. On the contrary, social aggression includes non-physical, indirect and relational aggression causing destructive social relations. To exclude someone from a social setting or carrying tales about someone could be given as examples of social aggression. These two types of aggression are common among the youth (Karriker et al., 2008).

Recent studies show that violence and aggression have reached serious dimensions among adolescents (Durmuş, 2013; Kurtoğlu, 2009; Yavuzer, 2009). A significant share in the increase in aggressive behavior belongs to the authorities for not taking necessary precautions (Durmuş and Gürgan, 2005). Literature review demonstrates that several studies found aggressive behavior worthy of research, especially concentrating on the reasons of aggressive behavior in adolescents (Anderson, 2004; Khoo, 2012; Norris, 2004). This study aimed to determine the differentiation of the games adolescents play in Internet cafes based on their gender, and their differences in aggression levels related to their gender, types of schools they attend, their academic standing and the games they play the most.

\section{METHOD}

\section{Research Model}

The study was conducted in descriptive research model to scrutinize aggression levels of adolescents that spend time in Internet cafes based on various variables. Descriptive studies examine an existing situation the way it is (Karasar, 2000). This study utilized the descriptive research method. When the aim of the study is considered, the use of descriptive model was deemed appropriate.

Universe and the Sample: Secondary school students passing time in Internet cafes in Elazığ city center in Turkey consist the universe of the study. The sample of the study was created using convenience sampling method and formed by 387 secondary school students, of which 119 were female and 268 were male, playing game in internet cafes in Elazığ, in Turkey.. The purpose was to construct a sample using entities that are related to the subject matter and could be accessed easily. Convenience sampling is formed by entities that participated the study voluntarily (Işıklar, 2012). The study was implemented at Internet cafes in Elazığ city center after obtaining a written permit from Elazığ office of the governor.

\section{Data Collection Tools}

As data collection tools of the study, to determine the dependent variable, aggression level, "Aggression Scale," to gather information on the independent variables, "Personal Information Form" developed by the author were used. The studies based on the data collection tools and general information are given below.

Aggression scale: The aggression scale first developed by Kocatürk (1982) and redeveloped by Tuzgöl (1988) based on the original aims to measure behavior related to overt, hidden, physical, verbal and indirect aggression in youth. It is 5-unit Likert-type scale with 45 items with a minimum score of 45 and the maximum possible score of 255 . Cronbach Alpha reliability score was 0.71 , and its Pearson Productmoment correlation was recalculated and found as $r: 0.85$. These values proved the usability of the scale. The study scrutinized the Cronbach Alpha internal consistency coefficient for the aggression scale, and it was found as 0.81 . 
Personal information form: Personal Information Form consisted of 4 questions about the independent variables related to the study subject matter to gather information on the personal characteristics of the students that participated in the study. Personal Information Form was developed by the author adhering to the purpose of the study and the independent variables mentioned in the study. Personal Information Form inquired about the gender, type of schools the students attended, their academic standing and the games they frequently played.

\section{Analysis of Data}

"Personal Information Form" and "Aggression Scale" was applied to the participants to gather the data. SPSS 18 software package was used in data analysis. Error level was accepted as 0.05 in the study. Frequencies, percentages, median, standard deviation, Levene test, t-test, one-way variance analysis (ANOVA) were utilized. In conditions where the variances were equal, Sheffe; when the variances were not equal, Donett $C$ tests were used (Büyüköztürk, 2002; Field, 2009).

\section{FINDINGS}

The most played games for female and male students are shown in Table 1.

Table 1

Results of Chi-square test of the most playing game type according to gender

\begin{tabular}{|llccccccc|}
\hline Gender & $\begin{array}{c}\text { 1.Sport } \\
\text { and } \\
\text { race }\end{array}$ & \multicolumn{2}{c}{$\begin{array}{c}\text { 2.Strategy } \\
\text { and } \\
\text { Adventure }\end{array}$} & $\begin{array}{c}\text { 3.Intelligence } \\
\text { and } \\
\text { Logic }\end{array}$ & $\begin{array}{c}\text { 4.War } \\
\text { and } \\
\text { Violence }\end{array}$ \\
\hline Female & $\mathrm{f}$ & $\%$ & $\mathrm{f}$ & $\%$ & $\mathrm{f}$ & $\%$ & $\mathrm{f}$ & $\%$ \\
\hline Male & 27 & 22.7 & 32 & 26.9 & 49 & 41.2 & 11 & 9.2 \\
\hline Total & 97 & 36.2 & 51 & 19 & 23 & 8.6 & 97 & 36.2 \\
\hline
\end{tabular}

$\mathrm{p}=.000, \mathrm{p}<.001$ Significant

Table 1 demonstrates that there was a significant difference between the most frequently played game for female and male students. While males preferred sports and racing (36.2\%) and war and violence themed (36.2\%) games, females played intelligence and logic-based games (41.2\%) more. Males preferred to play intelligence and logic themed games the least (8.6\%), females played war and violence themed games the least.

Aggression levels according to gender of students are shown in Table 2.

Table 2

Aggression Levels according to Gender of Students (Results of $t$ test)

\begin{tabular}{|c|c|c|c|c|c|c|}
\hline Gender & $\mathrm{n}$ & $\overline{\mathrm{X}}$ & Sd & $\mathrm{t}$ & $\mathrm{p}$ & Difference \\
\hline Female & 119 & 2.85 & .57 & \multirow{3}{*}{3.145} & \multirow{3}{*}{$.001^{*}$} & \multirow{3}{*}{ Male $>$ Female } \\
\hline Male & 268 & 3.04 & .46 & & & \\
\hline Total & 387 & & & & & \\
\hline
\end{tabular}

When the findings in Table 2 are examined with respect to gender, it would be observed that the aggression points average for males was $\bar{X}=3.04$ ) and the aggression points average for females was $\overline{\mathrm{X}}=2.85$ ). The findings observed in the table demonstrated that the aggression points for males were statistically significantly higher than the aggression points for females $(p=.001, p<.05)$.

Aggression Levels according to academic success of students are shown in Table 3 . 
Table 3

Aggression Levels according to academic success of students (Results of Oneway Anova Test)

\begin{tabular}{|c|c|c|c|c|c|c|c|c|c|}
\hline $\begin{array}{l}\text { Academic } \\
\text { Success }\end{array}$ & $n$ & $\overline{\mathrm{X}}$ & sd & Sum of Squares & & $\mathrm{df}$ & $\mathrm{F}$ & $p$ & Scheffe \\
\hline 1.Low & 80 & 3.19 & .45 & Between Groups & 7.144 & 2 & 14.754 & .000 & $1>3$ \\
\hline 2.Medium & 104 & 3.07 & .45 & & & & & & $2>3$ \\
\hline 3.High & 203 & 2.86 & .51 & Within Groups & 92.968 & 384 & & & \\
\hline Total & 387 & 2.98 & .50 & & 100.112 & 386 & & & \\
\hline
\end{tabular}

${ }^{*} p<.001$

When the findings in Table 3 are examined with respect to the academic standings of the students, it would be observed that the aggression points average for students who passed with poor grades was $(\overline{\mathrm{X}}=$ $3.19)$, the aggression points average for students who passed with good grades was $(\overline{\mathrm{X}}=3.07)$ and the aggression points average for students who passed with honor list grades was $(\overline{\mathrm{X}}=2.86)$.

The $F$ value obtained $(F(2-386)=14,754 ; p<.001)$ showed that there was a significant difference between the aggression levels of secondary education students based on their academic standings $(P=.000, p<.001)$. Scheffe test was applied after obtaining the above-mentioned findings to determine the groups that differed significantly among them. Findings demonstrated that aggression points of students that passed with poor grades were statistically significantly higher than the students in the honor list and the aggression points of students that passed with good grades were statistically significantly higher than the students in the honor list.

Aggression Levels according to the most playing computer games of students are shown in Table 4 .

Table 4

Aggression Levels according to the most playing computer games of students (Results of Oneway Anova Test)

\begin{tabular}{|c|c|c|c|c|c|c|c|c|c|}
\hline Most playing game type & $\mathrm{n}$ & $\overline{\mathrm{X}}$ & sd & \multicolumn{2}{|c|}{ Sum of Squares } & $\mathrm{df}$ & $\mathrm{F}$ & $p$ & Scheffe \\
\hline 1.Sport and Race & 124 & 3.02 & .47 & \multirow{2}{*}{$\begin{array}{l}\text { Between } \\
\text { Groups }\end{array}$} & \multirow[t]{2}{*}{6.235} & \multirow[t]{2}{*}{3} & \multirow[t]{5}{*}{8.479} & \multirow[t]{5}{*}{.000} & $1>3$ \\
\hline 2.Strategy and Adventure & 83 & 2.93 & .50 & & & & & & $4>2$ \\
\hline 3.Intelligence and Logic & 72 & 2.76 & .57 & \multirow{3}{*}{$\begin{array}{l}\text { Within } \\
\text { Groups }\end{array}$} & \multirow[t]{2}{*}{93.887} & \multirow[t]{2}{*}{383} & & & $4>1$ \\
\hline 4.War and Violence & 108 & 3.12 & .45 & & & & & & \\
\hline Total & 387 & 2.98 & .50 & & 100.112 & 386 & & & \\
\hline
\end{tabular}

${ }^{*} \mathrm{p}<.001$

When the findings in Table 4 are examined with respect to games most frequently played by the students, it was observed that the aggression points average for students who played sports and racing games was $(\overline{\mathrm{X}}=3.02)$, the aggression points average for students who played strategy and adventure games was $(\overline{\mathrm{X}}=$ $2.93)$, the aggression points average for students who played intelligence and logic games was $(\bar{X}=2.76)$ and the aggression points average for students who played war and violence games was $(\overline{\mathrm{X}}=3.12)$.

The $F$ value obtained $(F(3-383)=8.479 ; p<.05)$ showed that there was a significant difference between the aggression levels of secondary education students based on the games they frequently played $(P=.000$, $p<.05)$. Dunnett $C$ test was applied after obtaining the above-mentioned findings to determine the group averages that differed significantly among them. Findings demonstrated that aggression points of students that played sports and racing games were statistically significantly higher than the students that played intelligence and logic games and the aggression points of students that played war and violence games were statistically significantly higher than both the students that played strategy and adventure games and the students that played intelligence and logic games.

\section{DISCUSSION \& CONCLUSION}

The study aimed to examine the differences in the games adolescents play in Internet cafes based on their gender and the differences in their aggression levels based on various variables (gender, types of schools they attend, academic standing and types of games they play). Findings suggested that the games that students, who spent time in Internet cafes played differed based on their gender. While male students predominantly preferred sports and racing, and war and violence based games, they played intelligence and logic based games the least. On the other hand, the most preferred game type by females was intelligent and logic type games and the least preferred was war and violence games. In this context, it 
could be deducted that gender and preferred game types were differentiated. Literature review reveals parallel findings (Kars, 2010).

Another finding of the study demonstrated that aggression point averages for males $(\overline{\mathrm{X}}=3.04, \mathrm{Ss}=.57)$ were significantly higher than the aggression point averages for females $(\overline{\mathrm{X}}=2.85$, Ss $=.46)(\mathrm{p}=.001$, $\mathrm{p}<.05$ ). Literature review on studies on aggression levels based on gender demonstrates similar findings with this study (Björkqvist, 1994; Brooks, 1982; Burton, Hafetz and Henninger, 2007; Crane-Ross, Tisak and Tisak, 1998; Crick and Grotpeter, 1995; Douglas and Ayala, 1994; Espelage and Holt, 2008; Öztürk, 2008; Seals and Young, 2003). Findings of certain other studies suggested that the aggression levels for males and females were similar (Dilekmen, Ada and Alver, 2011; Underwood, Galenand and Paquette, 2001). It could be stated that the reason for the higher aggression levels of male students when compared to female students is different attitudes and behavior of families in raising their children in Turkish society. Because, it could be observed often in Turkish society that families have different sets of behavior when raising male and female children. For instance, while families welcome violent and aggressive behavior by their male children, they might not tolerate the same behavior by female children. This attitude reinforces physical aggression in males, thus resulting in a perception of violence as acceptable for males than females. Furthermore, adolescence is the zenith of an individual's powers; it is a period of daring. The individual is inclined to show off her or his power to the opponent (KIllç, 2013). These emotions and thoughts could be an indication of the efforts by an adolescent (especially males), who possess physical powers, to be accepted among peers by means of aggressive behavior.

When findings of the study was examined with respect to the academic standings of the students, it would be observed that the aggression points average for students who passed with poor grades was $(\bar{X}=3.19)$, the aggression points average for students who passed with good grades was $(\bar{X}=3.07)$ and the aggression points average for students who passed with honor list grades was $(\overline{\mathrm{X}}=2.86)$. Findings of the study demonstrated that there was a significant difference between the aggression levels of secondary education students based on their academic standings $(P=.000, p<.05)$. Findings showed that the students with the highest level of aggression points were those with the poor grades, while the honor list students had the lowest aggression points. Literature review demonstrated similar results with this finding of the study (López et al., 2006; Musito et al., 2004; Öztürk, 2008; Şahan, 2007). The low aggression level in students with high academic standing could be explained by the fact that these students spare their energy for studies, staying away from violent and aggressive environments, and have their teachers as role models as a result of closer relationship with them. It could be stated that successful students have better problem solving skills due to their high levels of self-confidence. Also, students with lower grades could make up for their lower academic standing by showing off physical power and by exhibiting aggressive behavior to gain status among peers. Because, it is a period problem that adolescent individuals engage in fights, join gangs to express their courage (Kılıç, 2013).

When findings of the study was examined with respect to the effects of the most frequently played games on the aggression point averages, it was observed that the aggression points average for students who played sports and racing games was $(\overline{\mathrm{X}}=3.02)$, the aggression points average for students who played strategy and adventure games was $(\overline{\mathrm{X}}=2.93)$, the aggression points average for students who played intelligence and logic games was $(\overline{\mathrm{X}}=2.76)$ and the aggression points average for students who played war and violence games was $(\overline{\mathrm{X}}=3.12)$. There was a significant difference between the aggression levels of students based on the games they frequently played $(P=.000, p<.05)$. The students with high aggression point averages were the ones playing war and violence games, followed by students playing sports and racing games and strategy and adventure games. Students with the lowest aggression points average were the ones who preferred to play intelligence and logic games. Literature review revealed similar results (Bavelier et al., 2011; Bilgi, 2005). Studies were concentrated on the causality relation that if playing games with aggressive content increase the aggressive tendencies or vice versa. A study by Evcin tried to answer that question and this study determined that those who play games with violent content for long periods of time displayed significantly higher levels of aggression (Evcin, 2010). In an experimental study conducted with primary school students in Çanakkale province, Günay aimed to measure possible changes in students' aggression levels after they played games with violent content. Within the context of the study, 10 students played games with violent content for 4 days and 20 minutes on each day. At the end of the 
study so significant increase in students' levels of aggression was observed (Günay, 2011). Aggressive behavior could emerge by changing directions as well. For example an individual who was criticized for her or his aggressive behavior could see violent and war games as a way out and could prefer to satisfy her or his needs for aggression through playing violent games. It could also be considered that, students who prefer to play intelligent and logical games, since they have the opportunity to develop skills to resolve handicaps that they face in these games, could therefore transfer these skills to develop logical solutions for problems into real life situations and thus they prefer to solve their problems without resorting to aggression.

Basic reasons that canalize adolescents to aggressive behavior could be researched in depth by interdisciplinary studies and specialists could design educational programs, seminars and television shows to reduce aggression levels. Bearing in mind the high aggression levels of students who play games with warfare and violent content, non-violent games that would attract the students more than the existing games with violent content could be developed and their use could be extended by public authority or with collaboration of the universities (by psychological counseling, psychology, computer engineering, computer programming, etc. departments). Bearing in mind the students with higher academic standings display less aggressive behavior, school psychological counselors and teachers could increase the interest of students in studies by activities (seminars, personal interviews, activities to keep the course content interesting, parent visits, create purpose in students) that would enhance the in-class participation of their students. This study was conducted only in Internet cafes in Elazığ city center; it could be considered that the sample was limited, in this respect, the study could be conducted nationwide to be more comprehensive. It has been observed that there were many quantitative studies aimed at adolescents in Turkey, in this context, future qualitative studies with adolescents who spend time in Internet cafes could contribute to the literature in a significant way.

\section{REFERENCES}

Aktaş, C. (2006). Türkiye'de bilgisayar ve internet kullanımının yaygınlaştırılmasında internet kafelerin rolü. İstanbul Üniversitesi Illetişim Fakültesi Hakemli Dergisi, (27), 1-16.

Anderson, C. A. (2004). An update on the effects of playing violent video games. Journal of Adolescence, 27, (1), 113-122.

Bavelier, D., Green, C. S., Han, D. H., Renshaw, P. F., Merzenich, M. M., \& Gentile, D. A. (2011). Brains on video games. Perspectives. 12, 763-768.

Bilgi, A. (2005). Bilgisayar oyunu oynayan ve oynamayan ergenlerin saldırganlık düzeylerinin incelenmesi (Yüksek Lisans Tezi). Marmara Üniversitesi/ Eğitim Bilimleri Enstitüsü, İstanbul.

Binark, M., \& Bayraktutan-Sütcü, G. (2007). Ankara mikro ölçeğinde internet kafeler kullanım biçimleri. XII. "Türkiye'de İnternet" Konferansı, Ankara.

Björkqvist, K. (1994). Sex differences in physical, verbal, and indirect aggression: A review of recent research. Sex Roles, 30, 177-188.

Brooks, V. R. (1982). Sex Differences in student dominance behavior in female and male professors' classrooms. Sex Roles, 8, (7), 683-690.

Burton, L. A., Hafetz, J., \& Henninger, D. (2007). Gender differences in relational and physical aggression. Social Behavior and Personality: an International Journal, 35, (1), 41-50.

Büyüköztürk, Ş. (2002). Sosyal Bilimler İçin Veri Analizi El Kitabı. Ankara: Pegem A Yayıncılık.

Corey, G. (2008). Psikolojik Danışma Kuram ve Uygulamaları (T. Ergene, Çeviren). Ankara: Mentis Yayıncılık (Orijinal eser 2005 yılında basılmıştır).

Crane-Ross, D., Tisak, M. S., \& Tisak, J. (1998). Aggression and conventional rule violation among adolescents: Social-reasoning predictors of social behavior. Aggressive Behavior, 24, (5), 347-365. 
Crick, N. R., \& Grotpeter, J. K. (1995). Relational aggression, gender, and social-psychological adjustment. Child Development, 66, (3), 710-722.

Çağlayan, S. (2001). Enformasyon toplumu: Internet kafeler ve kahvehanelerin karşılaştırmalı araştırması (Yüksek lisans tezi. Ege Üniversitesi, Sosyal Bilimler Enstitüsü, İzmir.

Çavuş, S., Ayhan, B., \& Tuncer, M. (2016). Bilgisayar oyunları ve bağımlılık: Üniversite öğrencileri üzerine bir alan araştırması. Iletişim Kuram ve Araştırma Dergisi, 2016(43).

Dilekmen, M., Ada, Ş., \& Alver, B. (2011) İlköğretim II. kademe öğrencilerinin saldırganlık özellikleri. Gaziantep Üniversitesi Sosyal Bilimler Dergisi, 10(2), 927 -944.

Donat Bacı, S. (2011). Çocuk ve Ergenlerde Şiddet ve Saldırganlığın Önlenmesi (Doktora Tezi). Dokuz Eylül Üniversitesi, Eğitim Bilimleri Enstitüsü, İzmir.

Douglas, P. F., \& Ayala, H. G. (1994). Preface: The cultural construction of gender and aggression. Sex Roles, 30, 165-167.

Durmuş, E. (2013). Ergen bakış açısıyla okulda şiddet ve çözüm önerileri. E-International Journal of Educational Research, 4(3), 41-57.

Durmuş, E. ve Gürgan, U. (2005). Lise Öğrencilerinin Şiddet ve Saldırganlık Eğilimleri. Türk Eğitim Bilimleri Dergisi. Cilt 3, Sayı 3, ss: 253-269.

Espelage, D. L. ve Holt, M. K. (2008). Bullying and Victimization During Early Adolescence. Journal of Emotional Abuse. Volume 2, Issue 2-3, ss: 123-142.

Field, A. (2009). Discovering Statistics Using Spss. London: Sage Publications Ltd.

Fikkers, K. M., Piotrowski, J. T., \& Valkenburg, P. M. (2016). Beyond the lab: Investigating early adolescents' cognitive, emotional, and arousal responses to violent games. Computers in Human Behavior, 60, 542-549.

Geçtan, E. (1994). Psikodinamik Psikiyatri ve Normal Dışı Davranışlar. İstanbul: Remzi Kitabevi.

Gençtarım Kuru, D. (2013). Ergenlerde Riskli Davranışların Yordanması (Yayınlanmamış Doktora Tezi). Hacettepe Üniversitesi/ Eğitim Bilimleri Enstitüsü, Ankara.

Griffiths, M. (1999). Violent Video Games and Aggression: A Review of The Literature. Aggression and Violent Behavior. Vol. 4, No. 2, pp. 203-212.

Günay, G. (2011). Şiddet Içerikli Online Bilgisayar Oyunlarının Ilköğretim Öğrencilerinin Saldırganlık Tepkileri Üzerindeki Etkisi (Yayımlanmamış Yüksek Lisans Tezi). Çanakkale 18 Mart Üniversitesi/ Sosyal Bilimler Enstitüsü, Çanakkale.

Işıklar, E. (2012). İstatistik. Eskişehir: Anadolu Üniversitesi Yayınları.

Kağıtçıbaşı, Ç. (2009). Saldırganlık ve Linç. 24.05.2014 tarihinde www.bilimvegelecek.com.tr internet adresinden erişildi.

Karasar, N. (2000). Bilimsel Araştırma Yöntemi-Kavramlar, Illkeler, Teknikler-10.Baskı. Nobel Yayınevi. Ankara.

Karriker, K. J., Karriker, J., Foshee, V. A., Ennett, S. T. ve Suchindran, C. (2008). The Development of Aggression During Adolescence: Sex Differences in Trajectories of Physical and Social Aggression Among Youth in Rural Areas. J Abnorm Child Psychol. November; 36(8): 1227-1236.

Kars, G. B. (2010). Şiddet içerikli bilgisayar oyunlarının çocuklarda saldırganlığa etkisi (Yüksek Lisans Tezi). Ankara Üniversitesi, Sağlık Bilimleri Enstitüsü, Ankara.

Khoo, A. (2012). Video Games As Moral Educators? Asia Pacific Journal of Education. Vol. 32, No. 4, December: 416-429.

Kılıç, M. (2013). Gerçek Yaşam Tadında: Gelişim Dönemleri 2, Erinlik-Ergenlik. Ankara: Pegem Yayınevi.

Kocatürk, R. (1982). Saldırganlık Güdüsünün Spor ve Eğitim Alanında Meslek Seçimine Etkisi (Yayınlanmamış Yüksek Lisans Tezi). Ankara Üniversitesi/ Sosyal Bilimler Enstitüsü, Eğitim Bilimleri Anabilim Dalı. 
Kumru Sarıca, A. (2008). Sosyal beceri programının ergenlerin saldırganlık düzeyine etkisi. Yayınlanmamış yüksek lisans tezi. Mersin Üniversitesi, Sosyal Bilimler Enstitüsü, Mersin.

Kurtoğlu, E. (2009). Lise Öğrencilerinde Görülen Saldırganlık Düzeylerinin Otomatik Düşünceler, Cinsiyet ve Sınıf Düzeyi Açısından Incelenmesi (Yayınlanmamış Yüksek Lisans Tezi). Ondokuz Mayıs Üniversitesi/ Sosyal Bilimleri Enstitüsü, Samsun.

Ögel, K. (2012). Internet Bağımlılığı. İstanbul: Türkiye İş Bankası Kültür Yayınları.

López, E. E., Olaizola, J. H., Ferrer, B. M., ve Ochoa, G. M. (2006). Aggressive and Nonaggressive Rejected Students: An Analysis of Their Differences. Psychology in the Schools.Volume 43, Issue 3, pages 387-400, March.

Marcus, R. F. (2007). Aggression and Violence in Adolescence. New York: Cambridge University Press.

Norris, K. O. (2004). Gender Stereotypes, Aggression, and Computer Games: An Online Survey of Women. Cyberpsychology \& Behavior. Volume 7, Number 6: 714-728.

Polcari, A., Rabib, K., Bolgerb, E. ve Teicher, M. H. (2013). Neglect Parental Verbal Affection and Verbal Aggression in Childhood Differentially Influence Psychiatric Symptoms and Wellbeingin Young Adulthood. Child Abuse \& Neglect. 38: 91-102.

Rink, E.., Tricker, R. ve Harvey, S. M. (2007). Onset of Sexual Intercourse among Female Adolescents: The Influence of Perceptions, Depression, and Ecological Factors. Journal of Adolescent Health. 41: 398 -406 .

Seals, D. ve Young, J. (2003). Bullying and Victimization: Prevalence and Relationship to Gender, Grade Level, Ethnicity, Self-Esteem, and Depression. Adolescence. Winter, Vol. 38. Issue 152, p735-747.

Şahan, M. (2007). Lise Öğrencilerinde Saldırganlığı Yordayan Bazı Değişkenlerin Incelenmesi (Yayımlanmamış Yüksek Lisans Tezi). Gazi Üniversitesi/ Eğitim Bilimleri Enstitüsü, Ankara.

Tarı Cömert, I., \& Kayıran, S. M. (2010). Çocuk ve ergenlerde internet kullanımı. Çocuk Dergisi, 10(4), 166170.

TUiK. (2017). Adrese Dayalı Nüfus Kayıt Sistemi Veri Tabanı. 06.05.2018 tarihinde rapor.tuik.gov.tr internet adresinden erişildi.

Tuzgöl, M. (1998). Ana-Baba Tutumları Farklı Lise Öğrencilerinin Saldırganlık Düzeylerinin Çeşitli Değişkenler Açısından Incelenmesi (Yayınlanmamış Yüksek Lisans Tezi). Hacettepe Üniversitesi/ Sosyal Bilimler Enstitüsü, Ankara.

Underwood, M. K., Galenand, B. R. ve Paquette, J. A. (2001). Top Ten Challenges for Understanding Gender and Aggression in Children: Why Can't We All Just Get Along? Social Development. Volume 10, Issue 2, pages 248-266, May.

WHO. (2013). Adolescent Health. 05.05.2014 tarihinde www.euro.who.int internet adresinden erişildi.

Yaman, E., Eroğlu, Y. ve Peker, A. (2011). Başaçıkma Stratejileriyle Okul Zorbalığı ve Siber Zorbalık. İstanbul: Kaknüs Yayınları.

Yavuzer, Y. (2009). Saldırganlı̆ı Önlemeye Yönelik Psiko-Eğitim Programlarının Lise Öğrencilerindeki Etkisinin Incelenmesi (Yayınlanmamış Doktora Tezi). Selçuk Üniversitesi/ Eğitim Bilimleri Enstitüsü, Konya. 